more beneficial results than those which in the past have been enjoyed by a restricted section of the industry. Every branch of instrument making is now effectively represented in the membership of the Association, and the opportunity exists for the in. fluence of the Association to spread in many new directions. In his speech at a luncheon which followed the opening ceremony, the Minister of Supply remarked, "The instrument makers look to the Association for help in solving their problems and overcoming their difficulties. From what I have learned of the Association, they will get this help. The memberfirms of the Association are supplied with a monthly Bulletin dealing with the latest results in research and development, and there is, in addition, a fund of technical information available in the excellent Library maintained by the Association. The achievements of the Association are far too many to enumerate; but I was interested to learn that nearly two hundred research reports have been issued by the Association, and these, I know, are of great interest to the manufacturers. The British Scientific Instrument Research Association is the oldest surviving research association connected with the Department of Scientific and Industrial Research, having been formed in 1918, when it had no more than nine members; to-day the membership exceeds one hundred. 'The Association's record is such that with the greatly increased facilities at Elmstead Woods it will be surprising if the present membership is not increased in the near future. The Association has already contributed greatly to the tools and instruments which have established the good name of British workmanship in the past, and I am sure it will maintain and even improve this reputation. . . . I would like to express the gratitude of the Government in general and of my own Ministry in particular for the great achievements of the Association in the past.",

\section{POLLUTION BY TRADE WASTES FROM FOOD INDUSTRIES}

$\mathrm{T}$ $\mathrm{HE}$ cause and effects of pollution by waste waters from food industries, and the prevention of this pollution, were discussed by Dr. B. A. Southgate and Dr. S. H. Jenkins at a joint meeting of the Food Group of the Society of Chemical Industry and the Midland Section of the Society held at Birmingham on May 23; Mr. T. Rendle presided.

Some waste waters contain directly toxic substances such as cyanides, phenols, and metallic compounds; in wastes from the food industries, however, pollution is due mainly to organic matter in solution and in suspension. Organic matter discharged into a stream is oxidized by bacterial action at the expense of the oxygen dissolved in the water. The rate of oxidation increases with rise in temperature; consequently a rise in temperature causes a decrease in the concentration of oxygen dissolved in the water, because this is the result of an equilibrium between the rate at which it is used in processes of oxidation and the rate at which it is absorbed from the atmosphere. As an illustration, in the winter the polluted estuary of the River Tees may contain dissolved oxygen equivalent to 70-80 per cent of the amount required to saturate the water, whereas in summer the corresponding concentration may be as little as 0 to 10 per cent af the saturation value. If the content of dissolved oxygen falls below about 50 per cent of the saturation value, the water may be unsuitable for fish, though they can live at much lower concentrations, particularly at low temperatures, at least for comparatively short periods.

Other effects of discharge of waste waters from the food industries include the deposition of organic sludge which may undergo anaerobic fermentation in warm weather, and which may cause marked changes in the distribution of bottom-living invertebrates, many of which serve as food for fish. Discharge of organic matter may also lead to the growth of 'sewage fungus'; this term is applied to a wide variety of Bacteria, Fungi, and Protozoa or associations of them, usually whitish-grey in colour and resembling cotton wool in appearance. These growths are found adhering to vegetation and stones in many polluted streams, and usually cause silting on the river bed. When the fungus dies it is decomposed by bacterial action, with absorption of oxygen from the water and sometimes with evolution of hydrogen sulphide.

Waste waters from food industries may cause difficulty in the use of surface waters for domestic supply; the presence of organic matter may make the water unpalatable; ammonia may interfere with the treatment of water by chlorination; and nitro. gonous compounds may stimulate growth of Algæ which cause difficulty in sand filters and may also give rise to unpleasant tastes.

When the construction of a food factory is being planned, the possibility of pollution resulting from trade effluents must be borne in mind. Pollution is sometimes avoidable by erecting factories where sewers and sewage disposal works are at hand to deal with any waste water. When vegetables or fruit must be conveyed to a factory in a fresh condition, this is not always possible, and treatment of the waste water at the factory then becomes necessary.

The volume of waste water produced and its impurity content varies greatly from factory to factory, depending upon the product made, the management, and the amount of water available for processing. The organic matter in the waste water can be expressed in terms of an equivalent amount of domestic sewage and therefore in terms of population. For example, a beet sugar factory handling 1,000 tons of beet daily may discharge up to four million gallons of waste water daily, containing organic matter equivalent, in some cases, to the sewage from about 2,000 persons and in other cases to the sewage from 20,000 persons. Food wastes show marked fluctuations in the polluting matter content because processing varies with the time of year : a tenfold increase in the polluting strength of the waste water within a matter of a fow weeks is not at all uncommon. This variation in strength, and also the fact that the wasto water is frequently produced over a short period of the day, introduces difficulties in designing treatment plants for purifying the factory wastes.

The methods used for purifying food wastes have developed from those employed for sewage treatment. Fibrous matter, rootlets, peelings, etc., are removed by passing the water through screens; suspended mineral matter is then separated and the organic matter in suspension removed by continuous passage through sedimentation tanks. The residual polluting matter in solution is eliminated by biological oxidation by : (1) allowing the liquid to percolate through suitable soil ; (2) distributing it over a filter bed made of inert material resting on a well-drained floor, so as to cultivate on the inert material a flora. 
and fauna able to oxidize the organic impurity in the waste water ; or (3) aerating a mixture of the waste water and a heterogeneous culture, known as activated sludge, which consists of organisms grown from the waste water.

All pollution prevention authorities agree that industrial wastes are best treated at sewage purification works. The Public Health (Drainage of Trade Premises) Act, 1937, gives manufacturers the right to use public sewers and sewage works for disposing of trade wastes, provided they do not injure structural materials or inhibit purification. Some food wastes, especially those from the fermentation industries, may cause very serious interference with treatment of the sewage when present in high concentration, but ordinarily the difficulties encountered are surmountable.

In discussion of the two papers, it was stated that the growths in a river receiving beet sugar waste had caused trouble on the screens at an electric power station ten miles below the factory. Wastes con. taining sugar favour such growths over a long stretch of river in cold weather : in warm weather, the sugar is rapidly oxidized and so the region of pollution is smaller, though the extent of pollution is greater. Decomposition of solid matter on the bed of a stream was also discussed. Anaerobic organisms break down such matter into gaseous products, or into substances which are then oxidized by aerobic organisms. The effects of Algæ were also mentioned. During the day, photosynthesis by Algæ raises the dissolved oxygen concentration in rivers, and when algal growth is marked, there is a diurnal variation in the dissolved oxygen content of the water. A prolific growth of Algæ might be followed by a lowering of the dissolved oxygen in the water when the Algæ die and decompose.

Further discussion was concerned with methods of analysis, means for assessing the amount of polluting matter in waste water, the treatment of wastes by means of chemical precipitants, the disposal of the sludge or solid matter in waste water, the dissolved oxygen content of sea water, and the difficulty of obtaining supplies of constructional materials for trade-waste purification plant.

\section{A NON-SPECIFIC RESISTANCE FACTOR IN THE ALBUMIN RESIDUE REVEALED BY THE SERIAL CEPHALIN FLOCCULATION CURVE}

\author{
By. DR. JACK G. MAKARI \\ Department of Bacteriology, American University \\ of Beirut, Lebanon
}

$\mathrm{N}$ the last laboratory meeting of the Royal Society 1 of Tropical Medicine, I demonstrated the various types of serial cephalin flocculation curves as obtained in health and disease with a special reference to their application in tropical derangements. In obtaining the curves, the serial dilution method was followed $^{1}$, using ten tubes instead of Hanger's original one-tube method ${ }^{2}$. Serial cephalin flocculation curve I, shown in the accompanying figure, represents the normal range in fifty healthy volunteers. In a study of the mechanism of Hanger's test, which is comparable to the first tube in the serial dilution method, Kabat, Hanger et al. ${ }^{3}$ found the flocculating factor to be associated with the $\gamma$ globulin. They failed, however, to find an inhibiting fraction in the albumins. Moore, Pierson et al.4, two years later, reported from the same laboratory the presence of an inhibiting fraction associated with the albumins. It is to be noted that these workers were using electrophoresis by means of which albumins appear homogeneous ${ }^{5}$. Dennis and Makari ${ }^{6}$, using salting-out methods, found the greatest concentrations of this inhibiting factor in the albumin residue. Since this inhibiting factor was found by the latter workers to be originally present in the serum in smaller amounts than the flocculating factor, the critical dilution-level of $0.04 \mathrm{mgm}$. is reached much earlier in the case of the inhibiting factor. The first zone representing the first five tubes in the figure presents, therefore, a delicate balance between flocculating factor ( $\gamma$ globulin) and inhibiting factor (albumin residue). In the second zone only the former is at work. This delicate balance in this first zone represents as well a balance between the liver and reticulo-endothelial system.
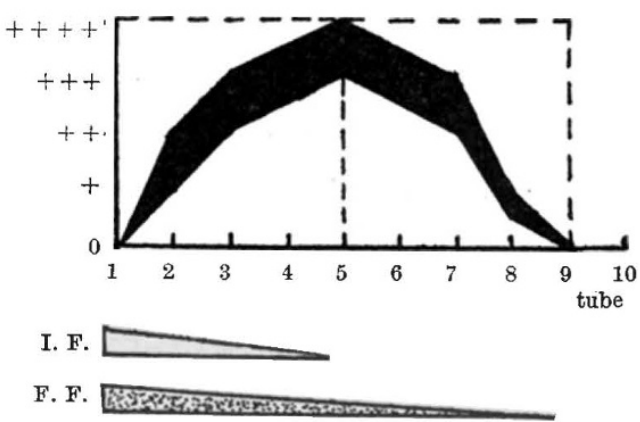

Further study: of this inhibiting factor present in the albumin residue of man and revealed by the first zone of the serial cephalin flocculation curve shows that it plays an important part in relation to drug administration, immunization, relapse and the outcome of infection in man.

The figures in the tables indicate the extent of deviation of this inhibiting factor from the normal range in health (serial cephalin flocculation curve I) recorded in $\frac{1}{8}$ in. square units. A deviation below the normal curve, that is, an increase in inhibition, is designated as positive, while a deviation in the opposite direction is designated as negative. Refer. ence to the dosage is made as follows : for quinine up to $3 \mathrm{gm}$. as small dose, 3-6 gm. as medium dose, and more than $6 \mathrm{gm}$. as large dose; for atebrin up to $0.6 \mathrm{gm}$. as small dose, between 0.6 and 1.2 gm. as medium dose, and larger amounts than $1 \cdot 2$ gm. as large dose.

Vaccination with T.A.B. was accomplished by the subcutaneous administration of 500 million bacteria; a double dose was given one week later and repeated one week later still. The typhoid cases studied were reported earlier in relation to Hanger's test?.

No reference is made in this preliminary report to changes in the flocculating factor which reflect reticulo-endothelial stimulation. This latter aspect will be referred to in the detailed report.

It is apparent from Table 1 that both quinine and atebrin give rise in healthy volunteers to a positive inhibiting factor response; atebrin resulting in greater stimulation over a shorter period.

A transient positive inhibiting factor response is also observed as a very early manifestation of 